Article

\title{
Investigation of the K-Mg-Ca Sulfate System as Part of Monitoring Problematic Phase Formations in Renewable-Energy Power Plants ${ }^{\dagger}$
}

\author{
Fiseha Tesfaye $\left.{ }^{1, *} \mathbb{(}\right)$, Daniel Lindberg ${ }^{2}\left(\mathbb{D}\right.$, Mykola Moroz $^{3,4}$ and Leena Hupa ${ }^{1}$ \\ 1 Johan Gadolin Process Chemistry Centre, Åbo Akademi University, Piispankatu 8, FI-20500 Turku, Finland; \\ leena.hupa@abo.fi \\ 2 Department of Chemical and Metallurgical Engineering, Aalto University, Kemistintie 1, \\ FI-02150 Espoo, Finland; daniel.k.lindberg@aalto.fi \\ 3 Department of Chemistry and Physics, National University of Water and Environmental Engineering, \\ Soborna 11, UA-33028 Rivne, Ukraine; m.v.moroz@nuwm.edu.ua \\ 4 Department of Physical and Colloid Chemistry, Ivan Franko National University of Lviv, \\ Kyrylo and Mefodiy 6, UA-79005 Lviv, Ukraine \\ * Correspondence: fiseha.tesfaye@abo.fi; Tel.: +358-503-211-876 \\ $+\quad$ This article is an extension of our paper published in Materials Processing Fundamentals 2018, TMS 2018 \\ Conference; The Minerals, Metals \& Materials Series. Springer, Cham, Switzerland, 11-15 March 2018; \\ pp. 133-142.
}

Received: 15 September 2020; Accepted: 11 October 2020; Published: 15 October 2020

\begin{abstract}
Besides the widely applied hydropower, wind farms and solar energy, biomass and municipal and industrial waste are increasingly becoming important sources of renewable energy. Nevertheless, fouling, slagging and corrosion associated with the combustion processes of these renewable sources are costly and threaten the long-term operation of power plants. During a high-temperature biomass combustion, alkali metals in the biomass fuel and the ash fusion behavior are the two major contributors to slagging. Ash deposits on superheater tubes that reduce thermal efficiency are often composed of complex combinations of sulfates and chlorides of $\mathrm{Ca}, \mathrm{Mg}, \mathrm{Na}$, and K. However, thermodynamic databases involving all the sulfates and chlorides that would favor a better understanding and control of the problems in combustion processes related to fouling, slagging and corrosion are not complete. In the present work, thermodynamic properties including solubility limits of some phases and phase mixtures in the $\mathrm{K}_{2} \mathrm{SO}_{4}-(\mathrm{Mg}, \mathrm{Ca}) \mathrm{SO}_{4}$ system were reviewed and experimentally investigated. Based on the new and revised thermochemical data, binary phase diagrams of the $\mathrm{K}_{2} \mathrm{SO}_{4}-\mathrm{CaSO}_{4}$ and $\mathrm{K}_{2} \mathrm{SO}_{4}-\mathrm{MgSO}_{4}$ systems above $400{ }^{\circ} \mathrm{C}$, which are of interest in the combustion processes of renewable-energy power plants, were optimized.
\end{abstract}

Keywords: sulfates; thermodynamic modeling; superheater tubes; high-temperature processes; slagging and fouling management

\section{Introduction}

The energy sector generates major greenhouse gas emissions globally. A move towards the increased production of energy from renewable sources across different economic sectors is vital to environmental protection. The utilization of renewable sources such as solid biomass, municipal waste and industrial waste for energy production is one of the available alternatives for reducing the use of fossil fuels. Furthermore, in an attempt to enhance self-sufficiency in energy, fossil fuel importing countries have recently planned to increase energy generation from renewable sources and optimize existing renewable-energy power plants. One of the motives to increase the use of renewable 
energy sources is the target set by the European Union [1]. In biomass-rich countries such as Finland, the energy produced from solid biomass (wood-based fuels) accounted for $25 \%$ of the total energy consumption in 2020 [2]. A large share of this energy comes from byproducts of the forest industry, including black liquor, bark, and sawdust. According to the recent review of Schmidt-Baum and Thrän [3], the share of solid biomass in the heating sector of EU in 2019 was 16.9\%, and there are ongoing efforts including regional government subsidies to develop larger biomass heating boilers with different heat loads. Biomass combustion for the production of heat and electricity is generally conducted in large industrial combustors such as fluidized bed boilers, black liquor recovery boilers, and grate-fired boilers.

Renewable fuels such as solid biomass require conversion prior to utilization. Thermochemical conversion methods such as combustion, gasification, and pyrolysis are some of the main options. Biomass combustion is one of the most developed conversion methods. In biomass combustion processes, alkali metal elements in the biomass fuels and the ash fusion behavior are the two major factors contributing to fouling and slagging during high-temperature combustion. These fouling and slagging problems threaten long-term operational availability and costs of biomass power plants [4-6]. For instance, renewable-energy power plants built in Northern China about 10 years ago have to shut down and clean the boiler every 20-30 days because of the fouling in the intermediate-temperature superheaters. Problematic fouling also often occurs on or near the bag filters of some boilers [7]. One of the main effects of the formation of slagging and fouling deposits is that they reduce the heat transfer process between the flame side and the water steam side and accelerate corrosion and erosion on the surfaces of superheaters and boiler tubes. These deposits also results in an increase in the flue gas temperature that reduces the efficiency of the plant system and increasing corrosion and erosion problems in the boilers [8,9]. According to reports of Enestam [8], corrosion control is regarded as a piece of a big puzzle for a power plant economic profitability; controlled corrosion minimizes the need for tube replacement (reduced maintenance cost), minimizes the frequency of plant shut-downs (increased plant availability) and maintains optimal plant efficiency during operations.

A high potassium concentration in renewable fuels tends to result in the formation of compounds with low melting points. Considerable amounts of the highly corrosive alkali chlorides in the flue gases are formed in these processes [10]. Slags on the intermediate-temperature superheaters constitute a considerable percentage of inorganic complex phases such as $\mathrm{K}_{2} \mathrm{Ca}_{2}\left(\mathrm{SO}_{4}\right)_{3}$. For example, the composition of the slag can be $\mathrm{KCl}-\mathrm{NaCl}-\mathrm{K}_{2} \mathrm{Ca}_{2}\left(\mathrm{SO}_{4}\right)_{3}$ [11]. $\mathrm{SiO}_{2}, \mathrm{KCl}, \mathrm{NaCl}, \mathrm{CaSO}_{4}, \mathrm{CaCO}_{3}$, $\mathrm{K}_{2} \mathrm{Ca}_{2}\left(\mathrm{SO}_{4}\right)_{3}, \mathrm{~K}_{2} \mathrm{CaMg}\left(\mathrm{SO}_{4}\right)_{3}$, and $(\mathrm{Na}, \mathrm{Ca}) \mathrm{Al}(\mathrm{Al}, \mathrm{Si})_{3} \mathrm{O}_{8}$ are reported to exist in some boiler ashes [12]. An example of the deposits build up on the heat exchangers is shown in Figure 1. Furthermore, Figure 1 depicts the three operational problems in combustion processes: fouling, slagging, and corrosion.

Phase relations and thermal stabilities in the multicomponent $\mathrm{K}-\mathrm{Ca}-\mathrm{Na}-\mathrm{Mg}-\mathrm{Cl}-\mathrm{S}-\mathrm{O}$ systems have been experimentally studied and reviewed by some researchers [12-15]. Crystal structures of some of the studied alkali sulfates are well-defined. However, unlike the binary compounds (such as chlorides, sulfides, oxides, etc.), the thermodynamic properties of the complex inorganic compounds have not been well studied. The importance of acquiring accurate thermochemical data in the prediction and control of inorganic materials deposition on the surfaces of the boiler tubes and superheaters is discussed in the following sub-section.

Previously, we have experimentally studied thermal stabilities of the simple sulfates $\mathrm{K}_{2} \mathrm{SO}_{4}$ and $\mathrm{CaSO}_{4}$ [16]. In the present work, thermodynamic properties including solubility limits of some phases and thermal stabilities of double sulfates in the $\mathrm{K}_{2} \mathrm{SO}_{4}-(\mathrm{Mg}, \mathrm{Ca}) \mathrm{SO}_{4}$ system were reviewed and experimentally investigated. Based on the revised and new thermochemical data, binary phase diagrams of $\mathrm{K}_{2} \mathrm{SO}_{4}-\mathrm{CaSO}_{4}$ and $\mathrm{K}_{2} \mathrm{SO}_{4}-\mathrm{MgSO}_{4}$ in the temperature range that would be of interest in the renewable-energy power plant processes were optimized. Recommended melt formation temperatures in the two studied systems have been compiled. All the thermodynamic calculations for the modeling were performed using the FactSage 7.1 software [17]. 


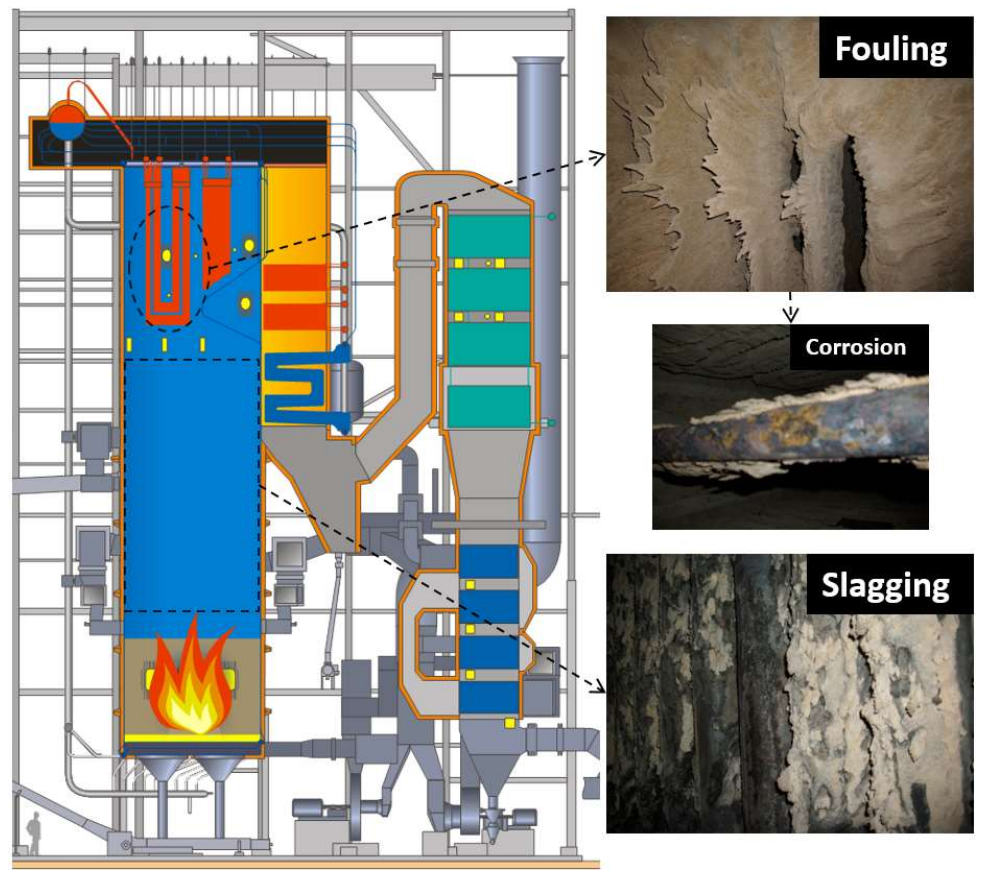

Figure 1. Schematic diagram of a boiler with magnified images showing ash-related problems—slagging, fouling, and corrosion—on the surfaces of furnace walls and superheater tubes.

\section{Thermochemical Data and Ash Deposits Prediction}

To avoid the intermediate temperature liquid phase formations, phases and phase mixtures that lie along the solidus and liquidus lines must be determined. These data will also help to understand corrosion mechanisms on the superheater surfaces and in the inner surfaces of the flash smelting boiler tubes. The role of thermodynamic data in the prediction and control of inorganic materials deposition and build up on the surfaces of the boiler tubes and superheaters is schematically presented in Figure 2. When composition of the feedstock is known, accurate data on the ash melting behavior together with furnace gas temperature can help to identify the sticky temperature range, a temperature range in which ashes contain certain amount of melt that lead to sticking and deposits build up on the surfaces of superheatrs and boiler tubes. In addition to solving problems related to unscheduled plant shut-down and additional operation costs, thermodynamic data on ash melting behavior can help to improve the materials design of boilers.

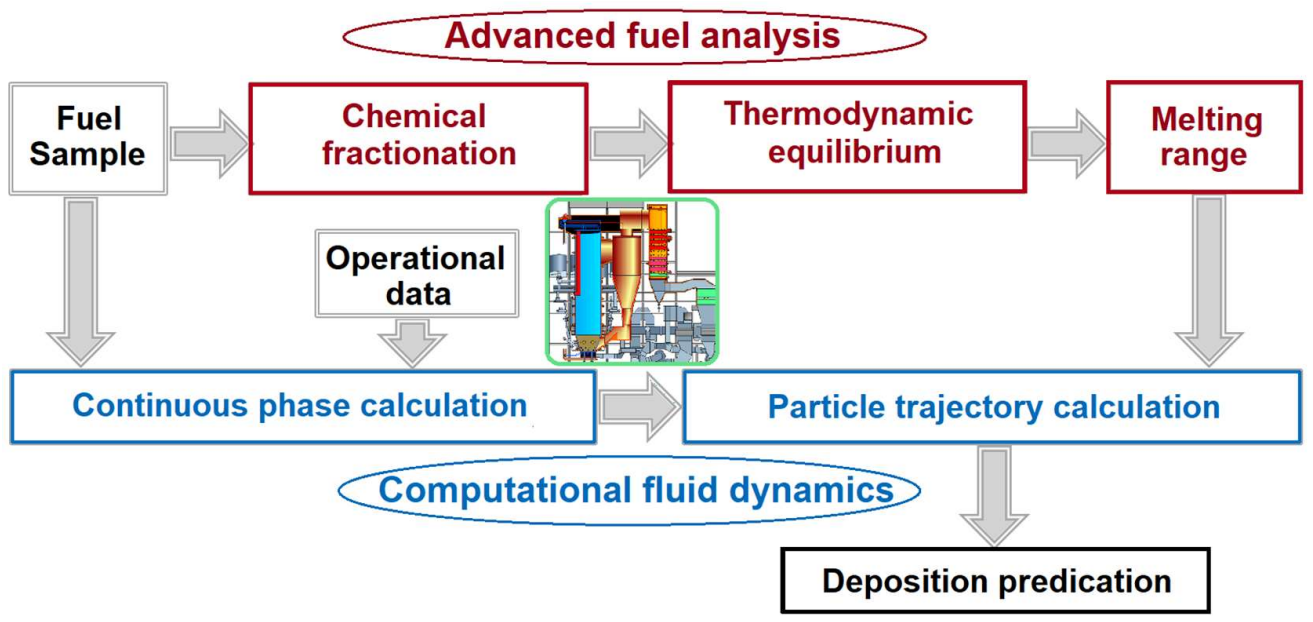

Figure 2. Schematic diagram showing novel concept for reliable prediction of deposition. The idea was adapted from [18] and modified. 


\section{Literature Data: Thermal Stabilities in the $\mathrm{K}_{2} \mathrm{SO}_{4}-\mathrm{CaSO}_{4}-\mathrm{MgSO}_{4}$ System}

Phase relations and thermal stabilities in the K-Ca-Mg-sulfate system have been experimentally studied and reviewed in the form of binary sulfate systems by several researchers [12-14,19-22], the system $\mathrm{K}_{2} \mathrm{SO}_{4}-\mathrm{MgSO}_{4}$, and [12-16,23-27] the system $\mathrm{K}_{2} \mathrm{SO}_{4}-\mathrm{CaSO}_{4}$. Unlike simple sulfates such as $\mathrm{K}_{2} \mathrm{SO}_{4}$, the thermodynamic properties of the double sulfates have not been studied thoroughly. Consequently, the thermodynamic properties of intermediate phases in the $\mathrm{K}_{2} \mathrm{SO}_{4}-\mathrm{CaSO}_{4}-\mathrm{MgSO}_{4}$ system are not well-defined. For instance, heat capacity measurements below $67^{\circ} \mathrm{C}$ are the only available experimental thermodynamic data for $\mathrm{K}_{2} \mathrm{Ca}_{2}\left(\mathrm{SO}_{4}\right)_{3}$ [15].

Phase diagram of the $\mathrm{K}_{2} \mathrm{SO}_{4}-\mathrm{MgSO}_{4}$ system was modeled in the past by $[14,19,22]$. Dissolution of $\mathrm{MgSO}_{4}$ in to $\mathrm{K}_{2} \mathrm{SO}_{4}$ was considered only in Grahmann's [22] phase diagram. The compound $\mathrm{Mg}_{2} \mathrm{Ca}_{2}\left(\mathrm{SO}_{4}\right)_{3}$ was previously reported as $\mathrm{Mg}_{3} \mathrm{Ca}\left(\mathrm{SO}_{4}\right)_{4}[14,28]$ and was found to be a minor constituent of the ash from several conventional coal-fired power plants $[29,30]$.

Phase diagram of the $\mathrm{K}_{2} \mathrm{SO}_{4}-\mathrm{CaSO}_{4}$ system was modeled in the late 1960 s by Rowe et al. [14] based on their and Bellanca's [25] experimental observations. In the proposed phase diagram of $\mathrm{K}_{2} \mathrm{SO}_{4}-\mathrm{CaSO}_{4}$ system, the high-temperature hexagonal $\mathrm{K}_{2} \mathrm{SO}_{4}$ dissolves a considerable amount of $\mathrm{CaSO}_{4}$, and the low-temperature orthorhombic $\mathrm{K}_{2} \mathrm{SO}_{4}$ may also dissolve minor amounts of $\mathrm{CaSO}_{4} \cdot \mathrm{K}_{2} \mathrm{Ca}_{2}\left(\mathrm{SO}_{4}\right)_{3}$ (calcium langbeinite) is the only intermediate stoichiometric phase to be identified in the system. Details on the thermodynamic properties of the double sulfates $\mathrm{K}_{2} \mathrm{Ca}_{2}\left(\mathrm{SO}_{4}\right)_{3}$ for which we have conducted experiment is discussed in the subsequent sections.

\section{Materials and Methods}

\subsection{Materials}

The provenance and purity of the starting materials used in this study were $99.999 \%$ pure $\mathrm{Ar}$ (gas) provided by AGA (Finland), $99.999 \%$ pure powders of $\mathrm{K}_{2} \mathrm{SO}_{4}$ delivered by Merck (Germany), and $99.0 \%$ pure powder of $\mathrm{CaSO}_{4} \cdot 2 \mathrm{H}_{2} \mathrm{O}$ delivered by Merck (Germany). The double sulfate $\mathrm{K}_{2} \mathrm{Ca}_{2}\left(\mathrm{SO}_{4}\right)_{3}$ was synthesized by mixing fine powders of the pure $\mathrm{K}_{2} \mathrm{SO}_{4}$ and $\mathrm{CaSO}_{4}$ in to 1:2 molar ratio. The phase mixture was annealed for 4 days at $800^{\circ} \mathrm{C}$ in a normally locked L51/SR muffle furnace (Nabertherm, Germany) with good heating control and a continuous flow of $\mathrm{N}_{2}$ (gas). The synthesis took place according to Reaction (1):

$$
2 \mathrm{CaSO}_{4}+\mathrm{K}_{2} \mathrm{SO}_{4} \leftrightarrows \mathrm{K}_{2} \mathrm{Ca}_{2}\left(\mathrm{SO}_{4}\right)_{3}
$$

\subsection{Methods}

Thermal analysis of the synthesized sample $\mathrm{K}_{2} \mathrm{Ca}_{2}\left(\mathrm{SO}_{4}\right)_{3}$ was performed by applying the differential scanning calorimetry (DSC) and thermogravimetry (TGA) method using a NETZSCH STA 449 F1 Jupiter ${ }^{\circledR}$-Simultaneous DSC-TGA equipment. The calorimeter was calibrated with the melting temperatures of high-purity metals, such as bismuth, tin, indium, zinc, aluminum and gold. The average temperature measurement accuracies were determined to be $\pm 1^{\circ} \mathrm{C}$.

PtRh-crucibles of the same mass were used as a base line (blank run), sapphire holder (for calibration) and sample holder in all DSC-TGA measurements. The measurements were performed on a total of five samples of the synthesized $\mathrm{K}_{2} \mathrm{Ca}_{2}\left(\mathrm{SO}_{4}\right)_{3}$. The initial weight of each sample was $60.4 \mathrm{mg}$ in all the measurements. Before each experimental run the chamber was evacuated and then backfilled with high-purity $\operatorname{Ar}($ gas) in three cycles. The $\operatorname{Ar}($ gas) with the flow rate $39 \mathrm{~mL} / \mathrm{min}$ was used as a protective gas in all runs. At the start of each experimental runs, the furnace was heated to $40^{\circ} \mathrm{C}$ and kept at an isothermal condition for $10 \mathrm{~min}$. Then, the furnace was heated to $1100{ }^{\circ} \mathrm{C}$ and cooled to $300{ }^{\circ} \mathrm{C}$ at a rate of $10^{\circ} \mathrm{C} / \mathrm{min}$, in both heat cycles. Weight losses and heat flows were measured simultaneously during the linear heating and cooling. 


\section{Thermodynamic Optimization}

The standard Gibbs free energy of stoichiometric compounds can be calculated by combining Equations (2) and (3) in accordance with Equation (4):

$$
\begin{gathered}
S_{T}^{o}=S_{298.15 \mathrm{~K}}^{o}+\int_{298.15 \mathrm{~K}}^{T}\left(\frac{C_{p}}{T}\right) d T \\
H_{T}^{o}=\Delta H_{298.15 \mathrm{~K}}^{o}+\int_{298.15 \mathrm{~K}}^{T} C_{p} d T \\
G_{T}^{o}=H_{T}^{o}-T S_{T}^{o}
\end{gathered}
$$

where $S_{298.15 \mathrm{~K}}^{o}$ and $\Delta H_{298.15 \mathrm{~K}}^{o}$ are the standard entropy and enthalpy of formation of a given species from pure elements, and $C_{p}$ is the temperature dependent heat capacity at constant pressure. $\Delta H_{298.15 \mathrm{~K}}^{o}$ is assumed to be $0 \mathrm{~J} / \mathrm{mol}$ for elemental species stable at reference state $T=298.15 \mathrm{~K}$ and $\mathrm{P}=1 \mathrm{~atm}$. To calculate the Gibbs energy of compounds accurately the other thermodynamic parameters should be determined based on experimental data or well proven estimation. High-temperature $C_{p}$ values of pure phases, for which experimental data is not available in the literature or experimental data acquisition is challenging, were estimated by the summation method described in [31], i.e., for example, the $C_{p}\left(\mathrm{~K}_{2} \mathrm{Ca}_{2}\left(\mathrm{SO}_{4}\right)_{3}\right)$ above $136^{\circ} \mathrm{C}$ was estimated from the experimentally determined $C_{p}$ values of $\mathrm{K}_{2} \mathrm{SO}_{4}$ and $\mathrm{CaSO}_{4}$ according to the reaction in Equation (1). All the thermodynamic assessments and calculations in this work were performed using the FactSage 7.1 software [17].

\section{Results and Discussion}

The obtained DSC-TGA vs. temperature results during heating and cooling of the sample $\mathrm{K}_{2} \mathrm{Ca}_{2}\left(\mathrm{SO}_{4}\right)_{3}$ in the temperature range from 40 to $1260{ }^{\circ} \mathrm{C}$ are shown in Figure 3 . The measured DSC and TGA curves for the five different samples were coinciding precisely. Due to the slight loss of mass $(0.48 \mathrm{wt} . \%)$ above the peak temperature $1020.4{ }^{\circ} \mathrm{C}$ (Figure 3), replication of the measurement for the same starting sample through reheating were not considered. On the heating DSC vs. temperature curves, temperatures of phase transition and melting appeared as sharp endothermic peaks. As the TGA vs. temperature curves in Figure 3A show, weight losses of the samples during heating cycles up to the melting peaks were negligible (below $0.06 \mathrm{wt} . \%$ ). The total weight loss up on heating to $1100{ }^{\circ} \mathrm{C}$ above the melting peak is $0.48 \mathrm{wt} . \%$; thus, expected reflections of the peaks on the cooling DSC curves were observed, for example, as solidification temperatures in the case melting temperatures. From the integral between the onset and end temperatures of the peak (shaded areas in Figure 3B), the enthalpy of phase transition and melting were determined and compiled in Table 1 together with their corresponding phase transition and melting temperatures. Heat capacity $\left(C_{p}(T)\right)$ for $\mathrm{K}_{2} \mathrm{Ca}_{2}\left(\mathrm{SO}_{4}\right)_{3}$ was determined from the stable DSC vs. T values that appear well before phase transition by comparing with the well-defined heat capacities of the reference, sapphire, as suggested by the manufacturer of a NETZSCH STA 449 F1 Jupiter ${ }^{\circledR}$ _Simultaneous DSC-TGA equipment.

\subsection{Thermochemical Data of Phases in the $\mathrm{K}_{2} \mathrm{SO}_{4}-\mathrm{CaSO}_{4}-\mathrm{MgSO}_{4}$ System}

The phase transitions and melting temperatures determined for $\mathrm{K}_{2} \mathrm{Ca}_{2}\left(\mathrm{SO}_{4}\right)_{3}$ in this study from the onset temperatures of the three distinct peaks on the DSC vs. temperature curve are: $200 \pm 1{ }^{\circ} \mathrm{C}$, $914 \pm 1{ }^{\circ} \mathrm{C}$ and $1010.6 \pm 1{ }^{\circ} \mathrm{C}$. The onset temperature $200 \pm 1{ }^{\circ} \mathrm{C}$ corresponds very well with the phase transition temperature of $\mathrm{K}_{2} \mathrm{Ca}_{2}\left(\mathrm{SO}_{4}\right)_{3}$ determined by Morey et al. [23], $200 \pm 2{ }^{\circ} \mathrm{C}$, and Cao et al. [15], $201.5 \pm 0.1{ }^{\circ} \mathrm{C}$. The phase transition temperature reported by Speer and Salje [32], $184^{\circ} \mathrm{C}$, is lower by about $16{ }^{\circ} \mathrm{C}$ than the result determined in this study and the result reported by $[15,23]$. 


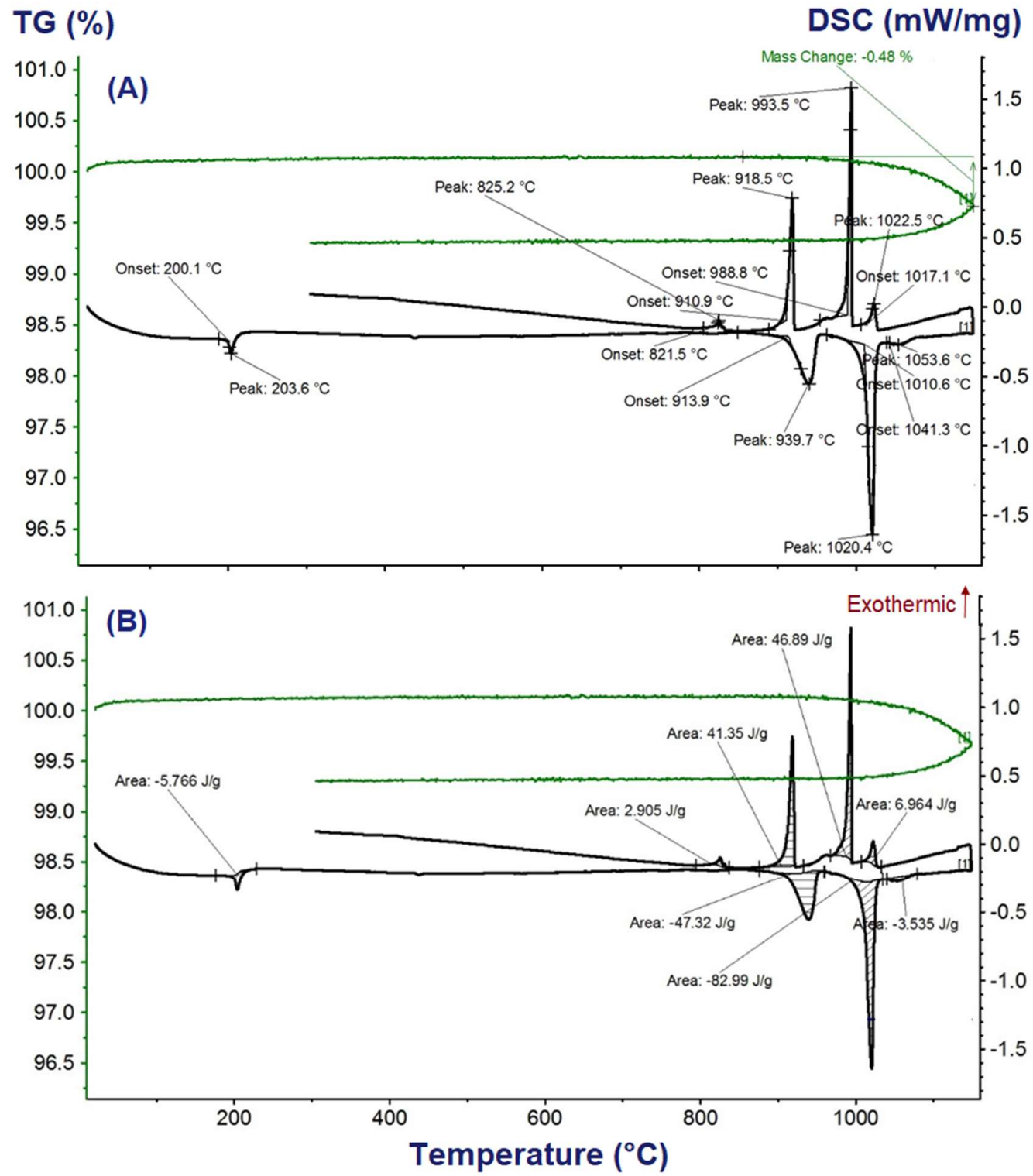

Figure 3. Differential scanning calorimetry-thermogravimetry (DSC-TGA) curves for the synthesized $\mathrm{K}_{2} \mathrm{Ca}_{2}\left(\mathrm{SO}_{4}\right)_{3}$ phase: (A) phase transition temperatures, and (B) highlighted areas of each peak for enthalpy of phase transition or melting calculations.

Table 1. Comparative summary of temperatures and enthalpies of phase transitions and melting of single phases in the $\mathrm{K}_{2} \mathrm{SO}_{4}-(\mathrm{Mg}, \mathrm{Ca}) \mathrm{SO}_{4}$ system.

\begin{tabular}{|c|c|c|c|c|c|c|}
\hline Phase & $T_{\operatorname{tra}(1)} /{ }^{\circ} \mathrm{C}$ & $T_{\operatorname{tra}(2)} /{ }^{\circ} \mathrm{C}$ & $\Delta_{\mathrm{tr}} \mathrm{H}^{\circ} / \mathrm{kJ} \cdot \mathrm{mol}^{-1}$ & $T_{\text {melt }} /{ }^{\circ} \mathrm{C}$ & $\Delta_{\text {melt }} H^{\circ} / \mathrm{kJ} \cdot \mathrm{mol}^{-1}$ & Ref. \\
\hline \multirow{3}{*}{$\mathrm{K}_{2} \mathrm{SO}_{4}$} & $586.1 \pm 1$ & None & $7.2 \pm 0.1$ & $1069.2 \pm 1$ & $21.12 \pm 0.3$ & [16] \\
\hline & 583 & & - & 1069 & - & {$[14,33]$} \\
\hline & 581 & & - & 1067 & - & [34] \\
\hline \multirow{4}{*}{$\mathrm{CaSO}_{4}$} & $1201 \pm 1$ & None & $9.1 \pm 0.1$ & - & - & [16] \\
\hline & $1195 \pm 2$ & & - & $1462 \pm 4$ & - & {$[14,24]$} \\
\hline & 1199 & & 29.43 & - & - & [33] \\
\hline & 1193 & & - & 1450 & 28.1 & [35] \\
\hline \multirow{3}{*}{$\mathrm{MgSO}_{4}$} & - & None & - & $1136 \pm 4$ & - & [14] \\
\hline & 1110 & - & - & 1130 & 14.6 & [35] \\
\hline & 1015 & - & 18.08 & - & - & [33] \\
\hline
\end{tabular}


Table 1. Cont.

\begin{tabular}{|c|c|c|c|c|c|c|}
\hline Phase & $T_{\operatorname{tra}(1)} /{ }^{\circ} \mathrm{C}$ & $T_{\operatorname{tra}(2)} /{ }^{\circ} \mathrm{C}$ & $\Delta_{\mathrm{tr}} H^{\circ} / \mathrm{kJ} \cdot \mathrm{mol}^{-1}$ & $T_{\text {melt }} /{ }^{\circ} \mathrm{C}$ & $\Delta_{\text {melt }} H^{\circ} / \mathrm{kJ} \cdot \mathrm{mol}^{-1}$ & 1 Ref. \\
\hline \multirow{6}{*}{$\mathrm{K}_{2} \mathrm{Ca}_{2}\left(\mathrm{SO}_{4}\right)_{3}$} & $200.1 \pm 1$ & $914 \pm 1$ & $2.6 \pm 0.1_{\operatorname{tra}(1)}$ & $1010.6 \pm 1^{1}$ & $37.1 \pm 0.6$ & This work \\
\hline & $201.5 \pm 0.1$ & - & $2.1 \pm 0.02_{\operatorname{tra}(1)}$ & - & - & [15] \\
\hline & 184 & - & - & - & - & [33] \\
\hline & - & 936 & - & $1004^{1}$ & - & [19] \\
\hline & - & 940 & - & $1011^{1}$ & - & [14] \\
\hline & $200 \pm 2$ & - & - & $1009-1013^{1}$ & - & [23] \\
\hline \multirow{2}{*}{$\mathrm{K}_{2} \mathrm{Mg}_{2}\left(\mathrm{SO}_{4}\right)_{3}$} & - & - & - & 943 & - & [23] \\
\hline & - & - & - & 930 & - & {$[19,20]$} \\
\hline
\end{tabular}

\section{Heat Capacity}

The $C_{p}$ functions for $\mathrm{K}_{2} \mathrm{SO}_{4}$ and $\mathrm{CaSO}_{4}$ were determined in our previous work [16]. The derived functions, Equations (5) and (6), for both substances agree with the values given in the handbook of Barin [36].

$$
\begin{gathered}
C_{P}\left(\mathrm{~K}_{2} \mathrm{SO}_{4}, \mathrm{~J} \cdot \mathrm{mol}^{-1} \mathrm{~K}^{-1}\right)=-224.0+0.4 T-6082803 T^{-2}-7.2 \times 10^{-5} T^{2}+5621.6 T^{-0.5} \\
C_{P}\left(\mathrm{CaSO}_{4}, \mathrm{~J} \cdot \mathrm{mol}^{-1} \mathrm{~K}^{-1}\right)=72.45+0.112 \cdot T-4.042 \times 10^{5} \cdot T^{-2}+3.862 \times 10^{-6} \cdot T^{2} \\
C_{P}\left(\mathrm{~K}_{2} \mathrm{Ca}_{2}\left(\mathrm{SO}_{4}\right)_{3}, \mathrm{~J} \cdot \mathrm{mol}^{-1} \mathrm{~K}^{-1}\right)=2208-7.03 \cdot T-44.5 \times 10^{6} \cdot T^{-2}+0.0081 \cdot T^{2}
\end{gathered}
$$

The $C_{p}$ functions for $\mathrm{K}_{2} \mathrm{Ca}_{2}\left(\mathrm{SO}_{4}\right)_{3}$ were calculated from the measured DSC vs. temperature values of the sample taking the well-defined $C_{p}$ values of sapphire as a reference. The experimental data below $130{ }^{\circ} \mathrm{C}$ were fitted by using the normal format $C_{p}$-data fit of HSC Chemistry 6 [37]. Cao et al. [15] determined $C_{p}$ values for $\mathrm{K}_{2} \mathrm{Ca}_{2}\left(\mathrm{SO}_{4}\right)_{3}$ up to $67^{\circ} \mathrm{C}$, based on results obtained with an adiabatic calorimeter. They reported the $C_{p}\left(\mathrm{~K}_{2} \mathrm{Ca}_{2}\left(\mathrm{SO}_{4}\right)_{3}\right)$ value at $25^{\circ} \mathrm{C}$ to be $343.6 \pm 0.7 \mathrm{~J} \cdot \mathrm{K}^{-1} \cdot \mathrm{mol}^{-1}$. Our calculation based on Equation (7) at the same temperature gives $331.4 \pm 1 \mathrm{~J} \cdot \mathrm{K}^{-1} \cdot \mathrm{mol}^{-1} \cdot \mathrm{C}_{p}\left(\mathrm{~K}_{2} \mathrm{Ca}_{2}\left(\mathrm{SO}_{4}\right)_{3}\right)$ values that are calculated by adding $C_{p}$ values of the simple sulfates (Equations (5) and (6)) at $25^{\circ} \mathrm{C}$ according to reaction in Equation (1), by the method described in [31], gave $C_{p}=334.6 \pm 1 \mathrm{~J} \cdot \mathrm{K}^{-1} \cdot \mathrm{mol}^{-1}$. This value is in agreement with the experimentally determined value in this work. In the thermodynamic modeling of the phase diagram of the $\mathrm{K}_{2} \mathrm{SO}_{4}-\mathrm{CaSO}_{4}$ system, we applied the experimental values determined in this study, and, for high-temperature phase regions, summations of the heat capacities of the simple sulfates method were applied. For $\mathrm{K}_{2} \mathrm{Mg}_{2}\left(\mathrm{SO}_{4}\right)_{3}$, the heat capacity and entropy data of Robie et al. [38] below $727{ }^{\circ} \mathrm{C}$ were applied together with the heat capacities estimated by adding heat capacities of the simple sulfates, $\mathrm{K}_{2} \mathrm{SO}_{4}$ and $\mathrm{MgSO}_{4}$.

\subsection{The $\mathrm{K}_{2} \mathrm{SO}_{4}-\mathrm{MgSO}_{4}$ System}

Phase diagram of the $\mathrm{K}_{2} \mathrm{SO}_{4}-\mathrm{MgSO}_{4}$ system in Figure 4 was optimized using the FactSage 7.1 software package [17]. The available literature data [14,19-22] were used in the optimization. The first liquid phase in the system appears at the eutectic temperature $737^{\circ} \mathrm{C}$. This temperature is lower than the eutectic temperature $750{ }^{\circ} \mathrm{C}$ reported in the Rowe et al. [14] and Grahmann [22] phase diagrams. With regard to the solid solubility limit of $\mathrm{MgSO}_{4}$ in $\mathrm{K}_{2} \mathrm{SO}_{4}$ (maximum 3.6 mol.\%), our optimization is in agreement with that of Grahmann [22]. The eutectic temperature Grahmann [22] reported for $\mathrm{MgSO}_{4}+\mathrm{K}_{2} \mathrm{Mg}_{2}\left(\mathrm{SO}_{4}\right)_{3}$, at $T=884{ }^{\circ} \mathrm{C}$, is lower by $9{ }^{\circ} \mathrm{C}$ than our optimized temperature. 


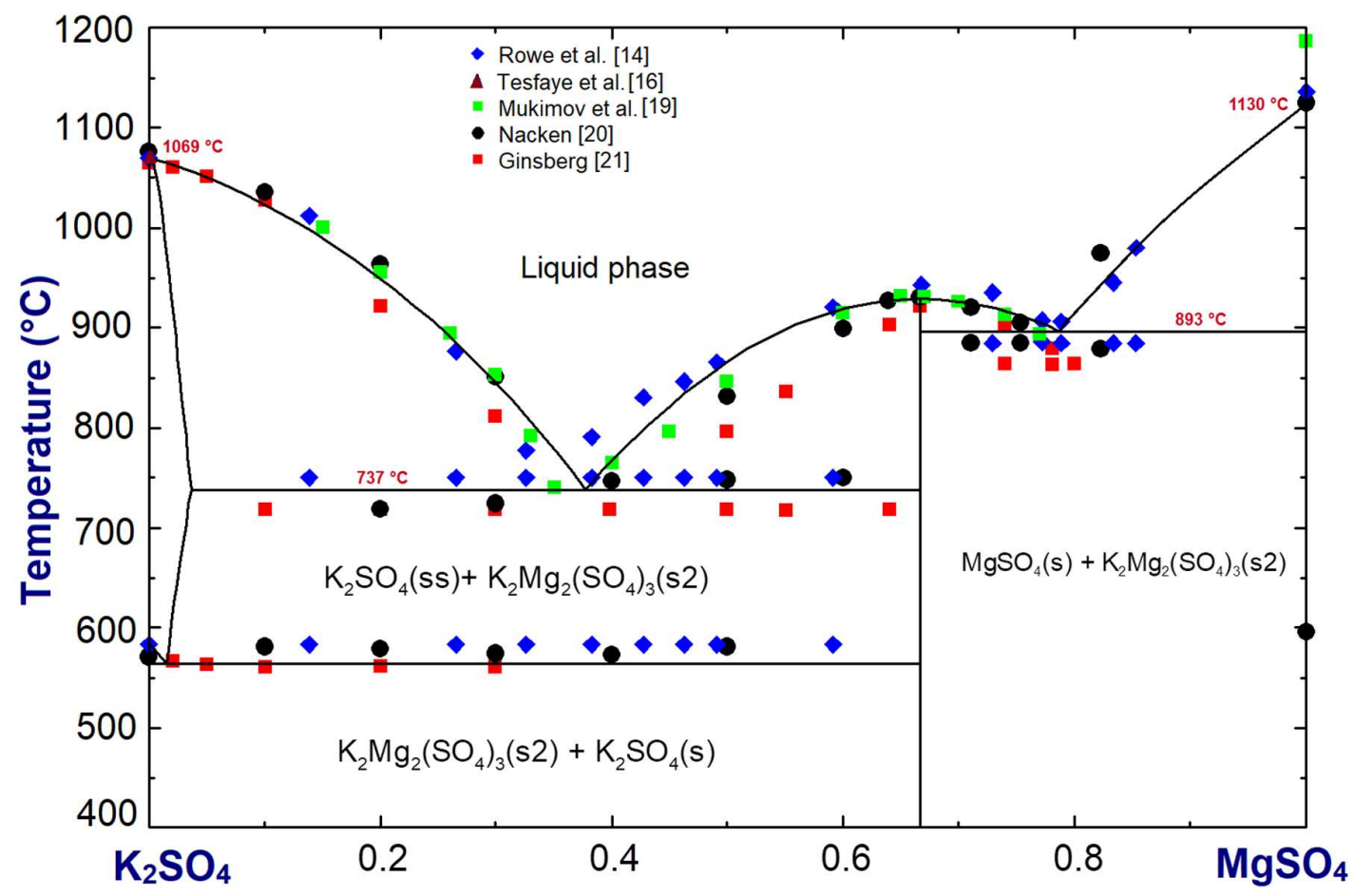

Figure 4. $\mathrm{K}_{2} \mathrm{SO}_{4}-\mathrm{MgSO}_{4}$ system optimized using the FactSage software package. Compositions are in mole fraction; (ss) indicates solid solution.

According to the experimental data of [14] shown in Figure 5, $\mathrm{K}_{2} \mathrm{Mg}_{2}\left(\mathrm{SO}_{4}\right)_{3}$ dissolves $\mathrm{CaSO}_{4}$ to form a solid solution that melts as low as $885{ }^{\circ} \mathrm{C}$ compared to the melting temperature of the pure $\mathrm{K}_{2} \mathrm{Mg}_{2}\left(\mathrm{SO}_{4}\right)_{3}, \mathrm{~T}=930^{\circ} \mathrm{C}$. However, the melting point rises again in the presence of excess of $\mathrm{CaSO}_{4}$ (>22 wt. \%).

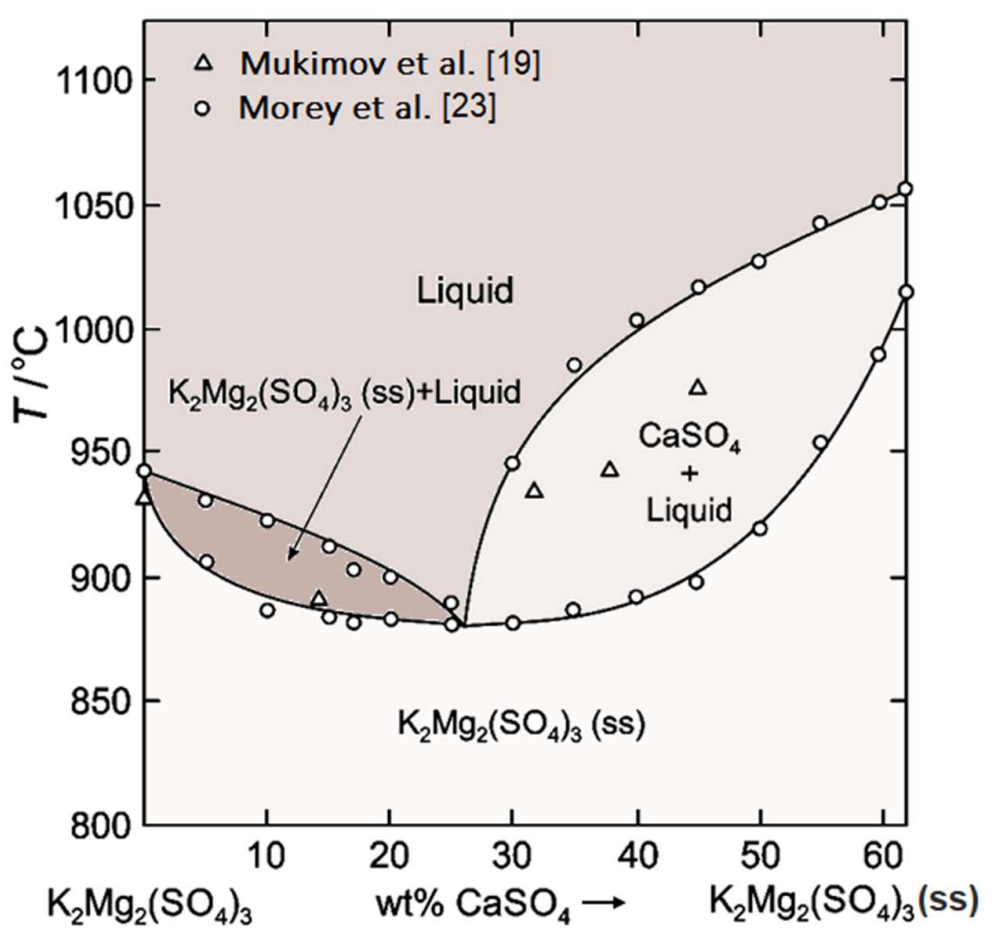

Figure 5. Phase relations on the tie line $\mathrm{K}_{2} \mathrm{Mg}_{2}\left(\mathrm{SO}_{4}\right)_{3}-\mathrm{CaSO}_{4}$ in the $\mathrm{K}_{2} \mathrm{SO}_{4}-\mathrm{MgSO}_{4}-\mathrm{CaSO}_{4}$ system, modified from [14]. 


\subsection{The $\mathrm{K}_{2} \mathrm{SO}_{4}-\mathrm{CaSO}_{4}$ System}

Phase diagram of the $\mathrm{K}_{2} \mathrm{SO}_{4}-\mathrm{CaSO}_{4}$ system presented in Figure 6 is also optimized using the FactSage 7.1 software package [17]. Prior to this optimization, the latest phase diagram of the system was proposed by Rowe et al. [14], in the late 1960s, and revised by Arceo and Glasser [26], in 1990. Similar to the $\mathrm{K}_{2} \mathrm{SO}_{4}-\mathrm{MgSO}_{4}$ system, it consists of a double sulfate $\mathrm{K}_{2} \mathrm{Ca}_{2}\left(\mathrm{SO}_{4}\right)_{3}$ that melts congruently at $1010.6{ }^{\circ} \mathrm{C}$. The optimized phase diagram of the system above $400{ }^{\circ} \mathrm{C}$ includes our experimental data presented in this work and in the previous paper from which this work has been extended of [16] as well as the literature data of $[14,23-27]$.

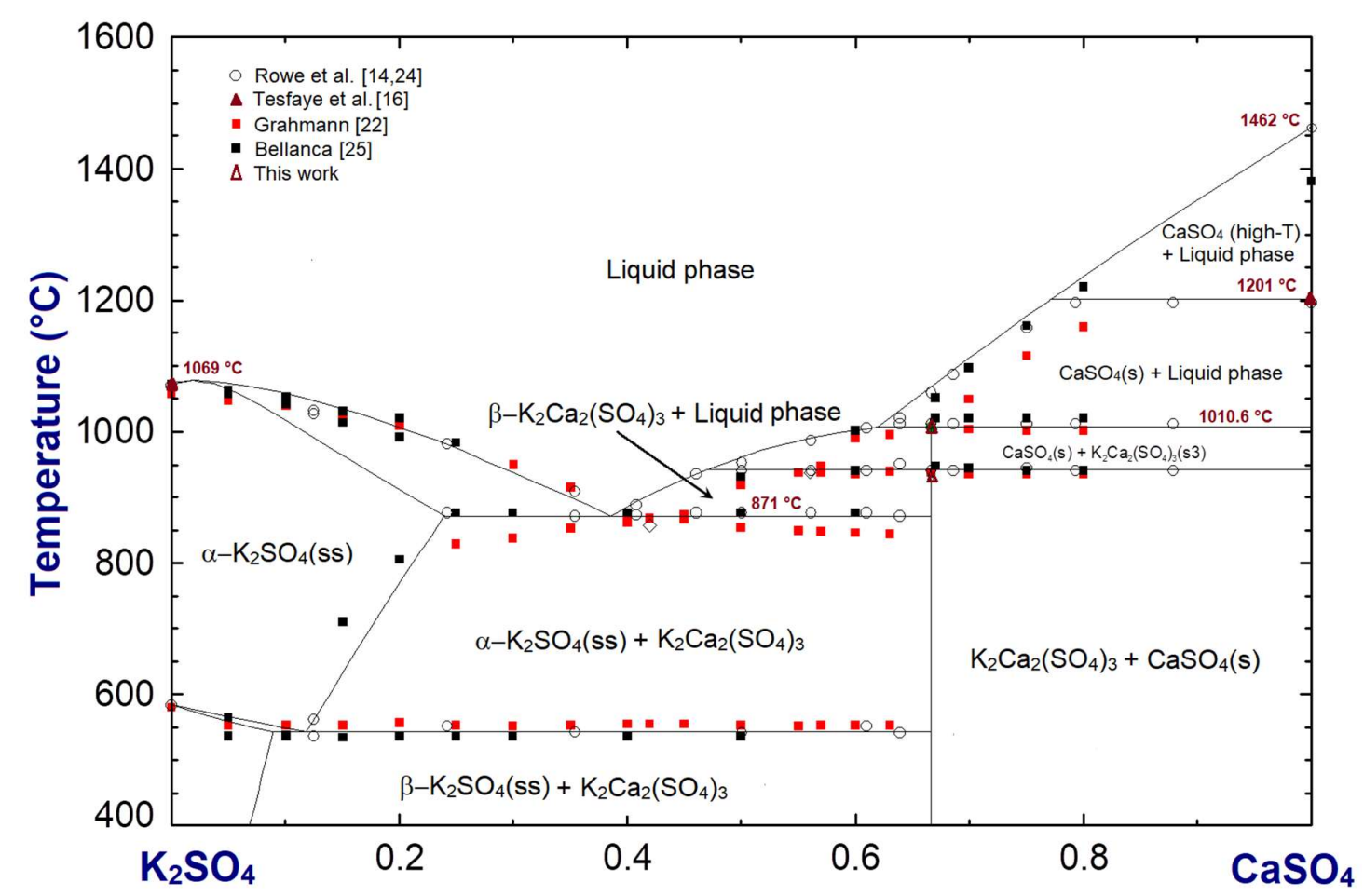

Figure 6. $\mathrm{K}_{2} \mathrm{SO}_{4}-\mathrm{CaSO}_{4}$ system optimized using the FactSage software package. Compositions are in mole fraction.

Unlike the $\mathrm{K}_{2} \mathrm{SO}_{4}-\mathrm{MgSO}_{4}$ system, the $\mathrm{K}_{2} \mathrm{SO}_{4}-\mathrm{CaSO}_{4}$ system constitutes the extensive solid solution of $\mathrm{CaSO}_{4}$ in $\mathrm{K}_{2} \mathrm{SO}_{4}$ (ss). The extent of the solid solution reported by [24-26] is in the range of the average value $24 \pm 4 \mathrm{~mol} \% \mathrm{~K}_{2} \mathrm{SO}_{4}$ reported by [27] and is considered in our revised phase diagram of the system. Melt-forming reactions and temperatures in the whole $\mathrm{K}_{2} \mathrm{SO}_{4}-\mathrm{MgSO}_{4}-\mathrm{MgSO}_{4}$ system that are optimized in this work are collected to Table 2.

Table 2. Summary of the optimized temperatures of melting and eutectic reactions in the $\mathrm{K}_{2} \mathrm{SO}_{4}$ $(\mathrm{Mg}, \mathrm{Ca}) \mathrm{SO}_{4}$ system. Decimals are rounded to the nearest whole number and a cumulative error range is $\pm 4{ }^{\circ} \mathrm{C}$.

\begin{tabular}{ccc}
\hline Reaction & $T_{\text {melt }}{ }^{\circ} \mathrm{C}$ & Remark \\
\hline $\mathrm{K}_{2} \mathrm{SO}_{4}+\mathrm{MgSO}_{4} \leftrightarrows \mathrm{K}_{2} \mathrm{SO}_{4}(\mathrm{ss})+$ & $737-1069$ & Melting of $\mathrm{K}_{2} \mathrm{SO}_{4}$ with solid solution \\
Liquid phase & & of up 3.6 mol. $\% \mathrm{MgSO}_{4}$ \\
$\mathrm{~K}_{2} \mathrm{SO}_{4}+\mathrm{CaSO}_{4} \leftrightarrows \mathrm{K}_{2} \mathrm{SO}_{4}(\mathrm{ss})+$ & $871-1069$ & Melting of $\mathrm{K}_{2} \mathrm{SO}_{4}$ with solid solution \\
Liquid phase & 1130 & of up 24.1 mol. $\% \mathrm{CaSO}_{4}$ \\
$\mathrm{MgSO}_{4} \leftrightarrows$ Liquid phase & 1462 & Congruent melting \\
$\mathrm{CaSO}_{4} \leftrightarrows$ Liquid phase & 930 & Congruent melting \\
$\mathrm{K}_{2} \mathrm{Mg}_{2}\left(\mathrm{SO}_{4}\right)_{3} \leftrightarrows$ Liquid phase & $885-930$ & Congruent melting \\
$\mathrm{K}_{2} \mathrm{Mg}_{2}\left(\mathrm{SO}_{4}\right)_{3}+\mathrm{CaSO}_{4} \leftrightarrows$ & & Melting of $\mathrm{K}_{2} \mathrm{Mg}_{2}\left(\mathrm{SO}_{4}\right)_{3}$ with solid \\
$\mathrm{K}_{2} \mathrm{Mg}_{2}\left(\mathrm{SO}_{4}\right)_{3}(\mathrm{ss})+$ Liquid phase & solution of up $18{\text { mol. } \% \mathrm{CaSO}_{4}}$ \\
\hline
\end{tabular}


Table 2. Cont.

\begin{tabular}{|c|c|c|}
\hline Reaction & $T_{\text {melt }} /{ }^{\circ} \mathrm{C}$ & Remark \\
\hline $\begin{array}{c}\mathrm{K}_{2} \mathrm{SO}_{4}(\mathrm{ss})+\mathrm{K}_{2} \mathrm{Mg}_{2}\left(\mathrm{SO}_{4}\right)_{3} \leftrightarrows \\
\text { Liquid phase }\end{array}$ & 737 & Eutectic melting \\
\hline $\begin{array}{c}\mathrm{MgSO}_{4}+\mathrm{K}_{2} \mathrm{Mg}_{2}\left(\mathrm{SO}_{4}\right)_{3} \leftrightarrows \\
\text { Liquid phase }\end{array}$ & 893 & Eutectic melting \\
\hline $\mathrm{K}_{2} \mathrm{Ca}_{2}\left(\mathrm{SO}_{4}\right)_{3} \leftrightarrows$ Liquid phase & 1011 & Congruent melting \\
\hline $\begin{array}{c}\mathrm{K}_{2} \mathrm{SO}_{4}(\mathrm{ss})+\mathrm{K}_{2} \mathrm{Ca}_{2}\left(\mathrm{SO}_{4}\right)_{3} \leftrightarrows \\
\text { Liquid phase }\end{array}$ & 871 & Eutectic melting \\
\hline $\begin{array}{c}\mathrm{K}_{2} \mathrm{Ca}_{2}\left(\mathrm{SO}_{4}\right)_{3}+\mathrm{CaSO}_{4} \leftrightarrows \text { Liquid } \\
\text { phase }+\mathrm{CaSO}_{4}\end{array}$ & 1011 & Congruent melting \\
\hline
\end{tabular}

\section{Conclusions}

The thermodynamic modeling of ashes is a useful tool for predicting ash behavior. It is often used to predict the melting behavior of phases and phase mixtures with implications for slagging, fouling and corrosion. To avoid the intermediate-temperature liquid phase formations, the phases and their mixtures that lie along the solidus and liquidus lines must be determined. However, due to several components or diverse chemistry and a lack of experimental data, it is challenging to have a complete thermodynamic database.

In this work, the $\mathrm{K}_{2} \mathrm{SO}_{4}-\mathrm{MgSO}_{4}$ and $\mathrm{K}_{2} \mathrm{SO}_{4}-\mathrm{CaSO}_{4}$ systems in the temperature ranges which are of interest in the combustion processes of renewable-energy power plants were reviewed, experimentally studied and optimized using the FactSage software package. According to the literature data, the pure $\mathrm{K}_{2} \mathrm{Mg}_{2}\left(\mathrm{SO}_{4}\right)_{3}$ phase melts at $930^{\circ} \mathrm{C}$. The optimization results in this work show that $\mathrm{K}_{2} \mathrm{Mg}_{2}\left(\mathrm{SO}_{4}\right)_{3}$ coexisting with excess $\mathrm{K}_{2} \mathrm{SO}_{4}$ (ss) melts at an eutectic temperature of $737^{\circ} \mathrm{C}$. This is lower by about $193{ }^{\circ} \mathrm{C}$ than the optimized melting temperature of the pure $\mathrm{K}_{2} \mathrm{Mg}_{2}\left(\mathrm{SO}_{4}\right)_{3}$ due to the effect of excess $\mathrm{K}_{2} \mathrm{SO}_{4}(\mathrm{ss})$. Moreover, $\mathrm{CaSO}_{4}$ was reported to readily dissolve into $\mathrm{K}_{2} \mathrm{Mg}_{2}\left(\mathrm{SO}_{4}\right)_{3}$ and lower its meting temperature by up to $52{ }^{\circ} \mathrm{C}$. The thermal stability of $\mathrm{K}_{2} \mathrm{Ca}_{2}\left(\mathrm{SO}_{4}\right)_{3}$ was experimentally studied by applying the DSC-TGA method. Based on the obtained results, its high-temperature phase transition and congruent melting temperatures were determined to be $914 \pm 1{ }^{\circ} \mathrm{C}$ and $1010.6 \pm 1{ }^{\circ} \mathrm{C}$, respectively. We have also determined the $C_{p}$ values for $\mathrm{K}_{2} \mathrm{Ca}_{2}\left(\mathrm{SO}_{4}\right)_{3}$ below $136^{\circ} \mathrm{C}$ experimentally, which served as a basis for extrapolation to high-temperature $C_{p}$ values. The heat of fusion of $\mathrm{K}_{2} \mathrm{Ca}_{2}\left(\mathrm{SO}_{4}\right)_{3}$, $\Delta_{\text {melt }} H^{\alpha \rightarrow \mathrm{L}}=37.1 \pm 0.6 \mathrm{~kJ} \cdot \mathrm{mol}^{-1}$, was also determined in this study for the first time. The results obtained were used to together with the literature data to optimize the $\mathrm{K}_{2} \mathrm{SO}_{4}-\mathrm{CaSO}_{4}$ system. Generally, the phase diagrams optimized based on critically selected literature data and experimental observation in this work contribute to the development of a larger databases that can be used for simulating and controlling the ash deposition and build up in renewable-energy power plants.

Author Contributions: Conceptualization, D.L. and F.T.; methodology, D.L. and F.T.; formal analysis, D.L. and F.T.; investigation, F.T., D.L., M.M. and L.H.; writing—original draft, F.T.; writing—review \& editing, L.H., D.L. and M.M.; supervision, D.L. and L.H.; project administration, F.T., D.L. and L.H.; funding acquisition, F.T., D.L. and L.H. All authors have read and agreed to the published version of the manuscript.

Funding: This research was funded by the Academy of Finland project "Thermodynamic investigation of complex inorganic material systems for improved renewable energy and metals production processes", Decision number 311537, as part of the Johan Gadolin Process Chemistry Center activities at Åbo Akademi University. The APC was funded by Åbo Akademi University. This work is also a part of the project clean and efficient utilization of demanding fuels (CLUE), with support from the industrial partners: ANDRITZ, Fortum, International Paper, UPM-Kymmene Corporation, and Valmet Technologies Oy.

Conflicts of Interest: The authors declare no conflict of interest.

\section{References}

1. European Commission (EC). Directive 2009/28/EC of the European Parliament and of the Council of 23 April 2009. Available online: http://data.europa.eu/eli/dir/2009/28/2015-10-05 (accessed on 14 August 2020). 
2. Official Statistics of Finland (OSF). Energy Supply and Consumption. Available online: http://www.stat.fi/til/ ehk/2020/01/ehk_2020_01_2020-06-30_tie_001_en.html (accessed on 31 August 2020).

3. Schmidt-Baum, T.; Thrän, D. Nine Measures to Take-Unlocking the Potential for Biomass Heat in the German Industry and the Trade, Commerce, and Service Sector. Energies 2020, 13, 4614. [CrossRef]

4. Vamvuka, D.; Zografos, D.; Alevizos, G. Control methods for mitigating biomass ash-related problems in fluidized beds. Bioresour. Technol. 2008, 99, 3534-3544. [CrossRef]

5. Lindberg, D.K.; Tesfaye, F. The Thermodynamics of Slag Forming Inorganic Phases in Biomass Combustion Processes. In Energy Technology 2017, TMS 2017; Zhang, L., Drelich, J., Neelameggham, N.R., Guillen, D.P., Haque, N., Zhu, J., Sun, Z., Wang, T., Howarter, J.A., Tesfaye, F., et al., Eds.; Springer: Cham, Swizerland, 2017; pp. 27-41.

6. Pettersson, A.; Amand, L.E.; Steenari, B.M. Chemical fractionation for the characterization of fly ashes from co-combustion of biofuels using different methods for alkali reduction. Fuel 2009, 88, 1758-1772. [CrossRef]

7. Niu, Y.; Tan, H.; Wang, X.; Liu, Z.; Liu, Y.; Xu, T. Study on deposits on the surface, upstream, and downstream of bag filters in a 12MWbiomass-fired boiler. Energy Fuel 2010, 24, 2127-2132. [CrossRef]

8. Enestam, S. Ash Related Challenges from a Boiler Manufacturer's Point of View: Chemistry in Energy Technology 2019. Available online: http://users.abo.fi/maengblo/CET_2019/6_Ash\%20related\%20challenges\% 202019\%20Enestam\%20_rev.pdf (accessed on 5 October 2020).

9. Febrero, L.; Granada, E.; Regueiro, A.; Míguez, J.L. Influence of Combustion Parameters on Fouling Composition after Wood Pellet Burning in a Lab-Scale Low-Power Boiler. Energies 2015, 8, 9794-9816. [CrossRef]

10. Karlsson, S.; Åm, L.-E.; Liske, J. Reducing high-temperature corrosion on high-alloyed stainless steel superheaters by co-combustion of municipal sewage sludge in a fluidised bed boiler. Fuel 2015, 139, 482-493. [CrossRef]

11. Zhu, Y.; Niu, Y.; Tan, H.; Wang, X. Short review on the origin and countermeasure of biomass slagging in grate furnace. Front. Energy Res. 2014, 2, 1-10. [CrossRef]

12. Ramsdell, L.S. An X-ray study of the system $\mathrm{K}_{2} \mathrm{SO}_{4}-\mathrm{MgSO}_{4}-\mathrm{CaSO}_{4}$. Am. Mineral. 1935, 20, 569-575.

13. Rowe, J.J.; Morey, G.W.; Zen, C.S. The Quinary Reciplocal Salt System $\mathrm{Na}, \mathrm{K}, \mathrm{Mg}, \mathrm{Ca} / \mathrm{Cl}, \mathrm{SO}_{4}-A$ Review of the Literature with New Data, No. 741; United States Government Publishing Office: Washington, DC, USA, 1972; pp. 1-37.

14. Rowe, J.J.; Morey, G.W.; Silber, C.C. Ternary system $\mathrm{K}_{2} \mathrm{SO}_{4}-\mathrm{MgSO}_{4}-\mathrm{CaSO}_{4}$. J. Inorg. Nucl. Chem. 1967, $29,925-942$. [CrossRef]

15. Cao, H.; Boerio-Goates, J. Heat-capacity measurements and thermodynamic functions of langbeinite-type $\mathrm{K}_{2} \mathrm{Cd}_{2}\left(\mathrm{SO}_{4}\right)_{3}$ and $\mathrm{K}_{2} \mathrm{Ca}_{2}\left(\mathrm{SO}_{4}\right)_{3}$ at temperatures from $10 \mathrm{~K}$ to $340 \mathrm{~K}$. J. Chem. Therm. 1994, 26, 251-259. [CrossRef]

16. Tesfaye, F.; Lindberg, D.; Hupa, L. The $\mathrm{K}_{2} \mathrm{SO}_{4}-\mathrm{CaSO}_{4}$ system and its role in fouling and slagging during high-temperature processes. In Materials Processing Fundamentals 2018, TMS 2018; Lambotte, G., Lee, J., Allanore, A., Wagstaff, S., Eds.; Springer: Cham, Swizerland, 2018; pp. 133-142.

17. Bale, C.W.; Bélisle, E.; Chartrand, P.; Decterov, S.A.; Eriksson, G.; Gheribi, A.E.; Hack, K.; Jung, I.-H.; Kang, Y.B.; Melançon, J.; et al. FactSage thermochemical software and databases, 2010-2016. Calphad 2016, 54, 35-53. [CrossRef]

18. Mueller, C.; Skrifvars, B.J.; Backman, R.; Hupa, M. Ash deposition prediction in biomass fired fluidized bed boilers-combination of CFD and advanced fuel analysis. Prog. Comput. Fluid. Dyn. 2003, 3, 113-120. [CrossRef]

19. Mukimov, S.M.; Krylova, N.I.; Bergman, A.G. Investigation of interaction in melts of sodium, potassium, magnesium and calcium sulfates. Trudy Inst. Khim. Akad. Nauk Uzbek SSR Inst. Khim Obshshaya: Neorff. Khim. 1949, 94, 94-132.

20. Nacken, R. Ueber Langbeinit und Vanthoffit $\left(\mathrm{K}_{2} \mathrm{SO}_{4} \cdot 2 \mathrm{MgSO}_{4}\right.$ und $\left.3 \mathrm{Na}_{2} \mathrm{SO}_{4} \cdot \mathrm{MgSO}_{4}\right)$. In Nachrichten von der Gesellschaft der Wissenschaften zu Göttingen; Mathematisch-Physikalische Klasse: Berlin, Germany, 1907; pp. 602-613.

21. Ginsberg, A.S. Uber die verbindungen von Magnesium- and Natriumsulfat. Z. Anorg. Allg. Chem. 1909, 61, 122-136. [CrossRef] 
22. Grahmann, W. Vergleich der Sulfate der Erdalkalien und des Bleis in den Temperaturkonzentrationsdiagrammen mit Kaliumsulfat unter besonderer Berücksichtigung der Dimorphie von Anhydrit, Cölestin, Baryt und Anglesit. Z. Anorg. Chem. 1913, 81, 257-314. [CrossRef]

23. Morey, G.W.; Rowe, J.J.; Fournier, R.O. The system $\mathrm{K}_{2} \mathrm{Mg}_{2}\left(\mathrm{SO}_{4}\right)_{3}($ Langbeinite $)-\mathrm{K}_{2} \mathrm{Ca}_{2}\left(\mathrm{SO}_{4}\right)_{3}$ (calciumlangbeinite). J. Inorg. Nucl. Chem. 1964, 26, 53-58. [CrossRef]

24. Rowe, J.J.; Morey, G.W.; Hansen, I.D. The binary system $\mathrm{K}_{2} \mathrm{SO}_{4}-\mathrm{CaSO}_{4}$. J. Inorg. Nucl. Chem. 1965, $27,53-58$. [CrossRef]

25. Bellanca, A. Identificazione e dosaggio delle modificazioni polimorfe dei minerali delle rocce mediante. Period. Mineral. 1942, 13, 21-85.

26. Arceo, H.B.; Glasser, F.P. Fluxing Reaction of Sulphates and Carbonates in Cement Clinkering Systems I. $\mathrm{CaSO}_{4}$ single bond $\mathrm{K}_{2} \mathrm{SO}_{4}$ single bond $\mathrm{CaCO}_{3}$. Cement and Concr. Res. 1990, 20, 862-868. [CrossRef]

27. Pliego-Cuervo, Y.B.; Glasser, F.P. The role of sulphates in cement clinkering reactions: Phase formation and melting in the system $\mathrm{CaO}-\mathrm{Ca}_{2} \mathrm{SiO}_{4}-\mathrm{CaSO}_{4}-\mathrm{K}_{2} \mathrm{SO}_{4}$. Cem. Concr. Res. 1977, 7, 477-482. [CrossRef]

28. Hubble, B.R.; Siegel, S.; Fuchs, L.H.; Hoekstra, H.R.; Tani, B.; Cunningham, P.T. The formation of $\mathrm{Mg}_{3} \mathrm{Ca}\left(\mathrm{SO}_{4}\right)_{4}$ during the sulfation reaction of dolomite. J. Air Pollut. Control Assoc. 1977, 27, 343-346. [CrossRef]

29. Chinchón, J.S.; Querol, X.; Fernández-Turiel, J.L.; López-Soler, A. Environmental impact of mineral transformations undergone during coal combustion. Environ. Geol. Water Sci. 1991, 18, 11-15. [CrossRef]

30. Havlíček, D.; Přibil, R.; Školoud, O. The chemical and mineralogical composition of the water-soluble fraction of power-plant ash and its effect on the process of crystallization of water. Atmos. Environ. 1993, 27A, 655-660. [CrossRef]

31. Tesfaye, F.; Lindberg, D. Thermochemical properties of selected ternary phases in the Ag-Bi-S system. J. Mater. Sci. 2016, 51, 5750-5759. [CrossRef]

32. Speer, D.; Salje, E. Phase transitions in langbeinites I: Crystal chemistry and structures of K-double sulfates of the langbeinite type $\mathrm{M}^{2++} \mathrm{K}_{2}\left(\mathrm{SO}_{4}\right)_{3}, \mathrm{M}^{++}=\mathrm{Mg}, \mathrm{Ni}, \mathrm{Co}, \mathrm{Zn}, \mathrm{Ca}$. Phys. Chem. Minerals 1986, 13, $17-24$. [CrossRef]

33. Torres, J.; Mendez, J.; Sukiennik, M. Transformation enthalpy of the alkali-earths sulfates $\left(\mathrm{SrSO}_{4}, \mathrm{CaSO}_{4}\right.$, $\left.\mathrm{MgSO}_{4}, \mathrm{BaSO}_{4}\right)$. Thermochim. Acta 1999, 334, 57-66. [CrossRef]

34. Wang, Z.; Yang, W.; Liu, H.; Jin, H.; Chen, H.; Su, K.; Tu, Y.; Wang, W. Thermochemical behavior of three sulfates $\left(\mathrm{CaSO}_{4}, \mathrm{~K}_{2} \mathrm{SO}_{4}\right.$ and $\left.\mathrm{Na}_{2} \mathrm{SO}_{4}\right)$ blended with cement raw materials $\left(\mathrm{CaO}-\mathrm{SiO}_{2}-\mathrm{Al}_{2} \mathrm{O}_{3}-\mathrm{Fe}_{2} \mathrm{O}_{3}\right)$ at high temperature. J. Anal. Appl. Pyrol. 2019, 142, 104617. [CrossRef]

35. Knacke, O.; Kubaschewski, O.; Hesselmann, K. Thermochemical Properties of Inorganic Substances, 2nd ed.; Springer: Berlin/Heidelberg, Germany, 1991.

36. Barin, I. Thermochemical Data of Pure Substances. Part I \& II, VCH Verlagsgesellschaft; Weinheim/VCH Publishers: New York, NY, USA, 1989.

37. Roine, A. HSC Chemistry for Windows, Version 6.1 and Its Database; Outotec Research Oy: Pori, Finland, 2007.

38. Robie, R.A.; Russell-Robinson, S.; Hemingway, B.S. Heat capacities and entropies from 8 to $1000 \mathrm{~K}$ of langbeinite $\left(\mathrm{K}_{2} \mathrm{Mg}_{2}\left(\mathrm{SO}_{4}\right)_{3}\right)$, anhydrite $\left(\mathrm{CaSO}_{4}\right)$ and of gypsum $\left(\mathrm{CaSO}_{4} \cdot 2 \mathrm{H}_{2} \mathrm{O}\right)$. Thermochim. Acta 1989, 139, 67-81. [CrossRef]

Publisher's Note: MDPI stays neutral with regard to jurisdictional claims in published maps and institutional affiliations.

(C) 2020 by the authors. Licensee MDPI, Basel, Switzerland. This article is an open access article distributed under the terms and conditions of the Creative Commons Attribution (CC BY) license (http://creativecommons.org/licenses/by/4.0/). 